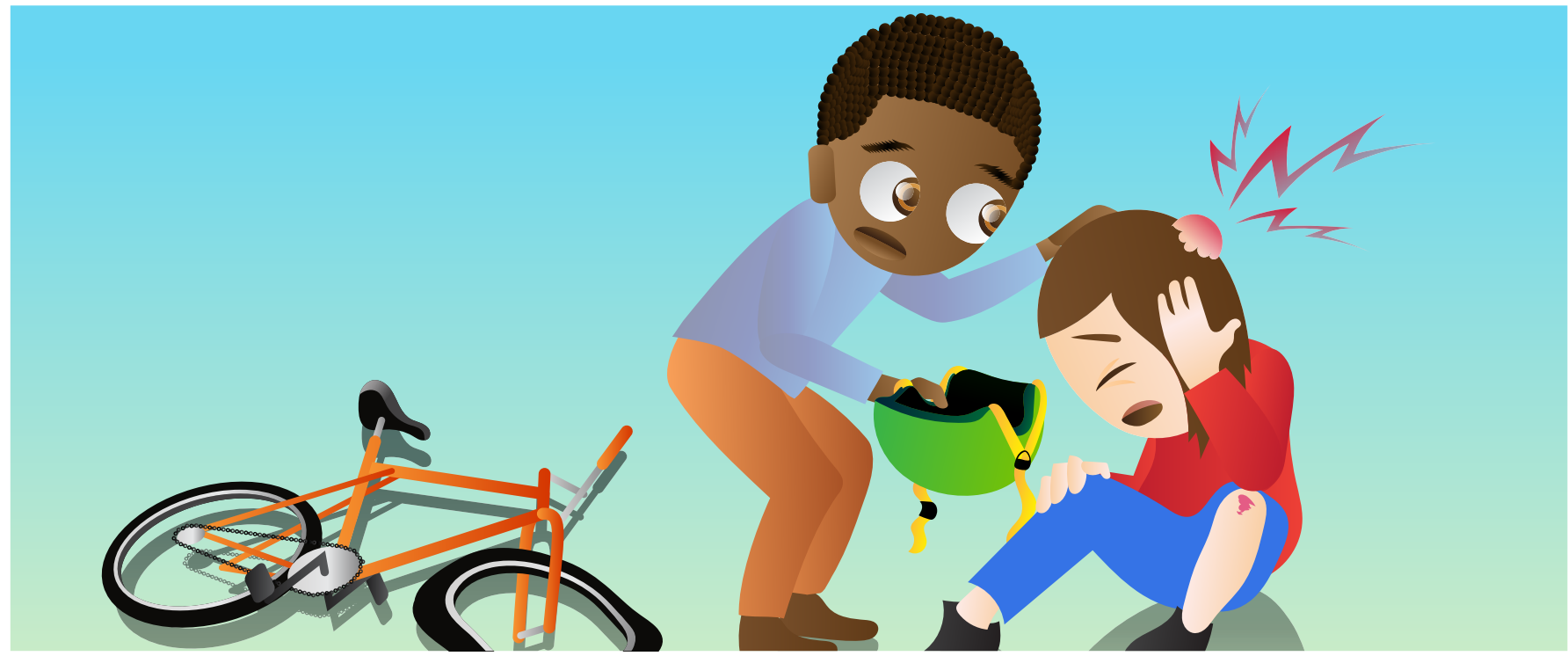

\title{
CARING FOR YOUR BRAIN: WHAT YOU NEED TO KNOW ABOUT CONCUSSIONS
}

Caroline J. Ketcham* and Eric E. Hall

Department of Exercise Science and Elon BrainCARE Research Institute, Elon University, Elon, NC, USA

REVIEWED BY:

DARIUS

12 YEARS OLD
Concussions are an injury to the brain that can result in several kinds of changes in the way the brain functions: changes in the way you think (cognitive changes), in the way your brain works (neurological changes), and in the way you feel (physical and emotional changes). Concussions can be caused by accidents where you hit your head on something like the ground, a tree, or another person. It is important to know the signs and symptoms of a concussion and what you need to do to allow your brain to heal properly. It is also important to know how to prevent concussions.

\section{INTRODUCTION}

Five little monkeys jumping on the bed, one fell off and bumped his head many activities we engage in involve running, jumping, and playing. Sometimes, activities are organized, for example, playing soccer or baseball. Other times you create games in your backyard with friends, go sledding when snow appears, or have other fun adventures in nature. All of these games and adventures are important for your body and your brain. Involvement in these activities is good for your body, as they make you stronger. These activities also help your brain learn to think and solve problems. Adventure 
and exploration are a big part of childhood, and it is good to grow up doing what you enjoy. Accidents happen though, including accidents to monkeys jumping on beds! Each year millions of kids are injured while riding bikes, sledding, or playing sports. Some of these injuries are visible, like a cut or a broken bone. However, the brain can be injured too, even though you cannot see it. It is important to know what you can do to protect your brain from serious injury and what you should do if you think you may have hurt your head. The best thing you can do if you hurt your head is take the time to recover appropriately and talk to others about how you are feeling. Then, you can get back to your adventures and exploration - because those things are important too.

\section{WHAT IS A CONCUSSION?}

A concussion is an injury to the brain that is caused by a sudden, abrupt movement of the head, typically because of a blow or jolt to the head or body that makes the brain move rapidly inside the skull (Figure 1).

The injury that results from this is called a mild traumatic brain injury, most commonly referred to as a concussion. There are many different definitions of concussion, but they all have some things in common. These common features include changes in brain function, including changes in the way you think (cognitive changes), in the way your brain works (neurological changes), and in the way you feel (physical and emotional changes). These changes may or may not be accompanied by a temporary loss of consciousness, also known as fainting or passing out [1]. The abrupt movement of the brain can stretch and injure brain cells, which can change the way these cells function. These

\section{FIGURE}

This is how your brain moves in your skull when you are hit (http:// ucresearch.tumblr.com/ post/131237007666/thisis-your-brainexperiencing-aconcussion-it).

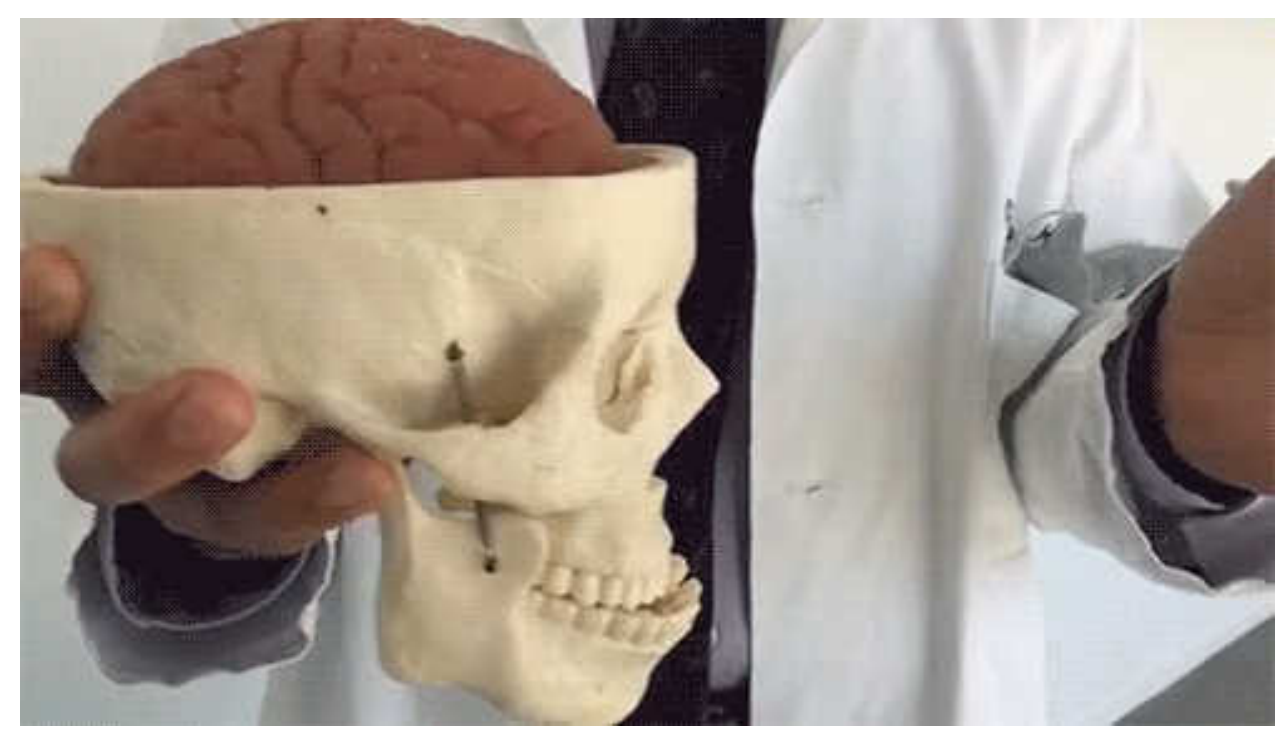

FIGURE 1 
changes can be short-lived or long-lived, but most of the time, the cells heal and function normally in 7-10 days [2].

Sometimes, it may take longer than 10 days for the brain to return to normal after a concussion, especially in children. Because it is not possible to "see" the changes that happen in your brain or how your brain is healing, it is very important to know the signs and symptoms of a concussion and to tell an adult what you are feeling. That way, everyone can get a better idea of how your brain is healing [3].

\section{SYMPTOMS OF A CONCUSSION}

When you hit your head, these signs and symptoms may happen right away, or they may take a few hours or even a day to start. How do you know if you have a concussion? Usually, people will report that they "don't feel right." These are some of the symptoms that you might notice in yourself if you have a concussion [4]:

- Headache or "pressure" in the head;

- Nausea or vomiting;

- Balance problems or dizziness, or double or blurry vision;

- Bothered by light or noise;

- Feeling sluggish, hazy, foggy, or groggy;

- Confusion, concentration, or memory problems;

- Just not "feeling right," or "feeling down."

Other people, such as friends, parents, and teammates, are also helpful in determining if you have a concussion, because they might notice certain signs or symptoms that you will not notice yourself. These are some of the common signs that they might observe in a child with a concussion:

- The child cannot recall events that happened before or after the hit or fall;

- The child appears dazed or stunned;

- The child forgets instructions, is confused about an assignment or position, or is unsure of the game, score, or opponent;

- The child moves clumsily;

- The child answers questions slowly;

- The child loses consciousness (even briefly);

- The child shows mood, behavior, or personality changes.

These signs and symptoms can be very serious, and they can make it hard to do the things that you want to do. Therefore, if you feel these symptoms or see them in someone else, it is very important to report them to an adult. 


\section{WHAT SHOULD I DO IF I HAVE A CONCUSSION?}

If, after an accident, you are not feeling right and think you might have a concussion, it is very important that you report your symptoms to an adult. Depending on where you are when injury happens, this adult could a teacher, coach, or your parents. Sometimes, athletes do not want to report that they may have a concussion because they want to keep playing or they are afraid that they will let their team down. It is important to remember that you are injured and your health is more important than whether you win or lose a game! If you think a friend does not seem right after being hit in the head, you should also help them out by making sure that they tell an adult, or you can tell an adult what happened. Because it is often hard to see that a concussion has happened, parents and doctors will rely on you to be honest and tell them what symptoms you are having. If you start feeling worse, it is very important to tell someone.

\section{WHAT SHOULD PARENTS AND COACHES DO IF THEY SUSPECT A CHILD HAS A CONCUSSION?}

Concussions are especially dangerous because you cannot see the actual injury; therefore, adults must rely on the child to report that they have been hit in the head and ask them to describe any symptoms they have that might be related to a concussion. Adults should monitor the injured child to see if there are any signs of a concussion and to see if the child is acting differently or just does not seem quite right. If an adult suspects that a child has a concussion, the child should be removed from play or stop doing what they were doing, so that they can be monitored. It is then important to seek out appropriate medical attention to have the child evaluated, so that they can receive the proper treatment. Parents and coaches should provide a supportive environment, so that children will report that they have been hit in the head and possibly have a concussion. Also, adults should not let the injured child back to play until they have been cleared by a doctor.

\section{WHEN CAN SOMEONE WITH A CONCUSSION RETURN TO PLAY OR SCHOOL?}

Now, you know that it is important to let your brain heal after a concussion, before you go back to adventures and school. But how do you know if your brain is ready to go back? The signs and symptoms of a concussion are your best measure of how your brain is healing. The recommendation is at least 24-48 h of complete mental and physical rest. That means no screen time (e.g., texting, TV, and computer), and no running, jumping, spinning, or swinging. You will also need to stay out of school because thinking and problem solving is hard for your brain, too. After the first $24-48 \mathrm{~h}$, you may work with your 
doctor to start adding back in activities to see how you feel when you do them. Do those symptoms return? For example, you might try to read for a bit or go for a walk. How do you feel? You should continue to increase the amount of work your brain does and what it is exposed to, including loud noises and bright lights. If at any point your symptoms increase, then take a break from that activity for a bit longer. This might mean telling your parents or a teacher that you do not feel right. Your brain is still healing. When reading, screen time, lights and noises do not seem to increase symptoms, then try getting your heart rate up and see how you feel. Go for a run or a bike ride and if symptoms return take a bit more time off. It is very easy to reinjure your brain while it is healing. So, make sure to let it heal all the way before you get back to adventures, exploration, and playing sports. During this recovery time, continue to be honest about your symptoms and listen to the recommendations of your doctor and parents [5].

\section{HOW DO I PREVENT A CONCUSSION?}

Since you now know that it is very important to protect your brain, but also know that it is important to be adventurous, how do you protect your brain? Hopefully, you wear a helmet when you ride your bike, skateboard, or ski. But do you wear it when you go sledding or on a zip line? These are also adventures that may lead to you hitting a tree or the ground hard enough to cause a concussion. A helmet is a great protector for your brain, although you can still get a concussion while wearing one. Some states have laws about the activities that require helmets and the required age for wearing a helmet (for example, biking under 16 years of age), but there is never a law that you cannot wear a helmet; so, be as safe as possible and wear a helmet whenever you do anything adventurous! You should also wear head protection during sports, like a helmet for football or head padding for martial arts. Wearing head protection may feel a little weird at first, but it is better to be safe than sorry. Some sports require helmets to be worn, and in these sports, it is helpful to make sure that your helmet fits you well. If your helmet does not fit snugly, see if you can find one that fits you better. If you notice any cracks or damage to the helmet, make sure to tell your coach, so that he can make sure it is replaced or fixed. It is also important to learn good mechanics and form when you play sports. Your coach will teach you how to tackle someone or to head a soccer ball. Listen carefully and use your strong body, not your head, to play. If you do not use proper technique, you might put yourself or someone else at risk for a concussion. Examples of proper form include making sure you tackle with your head up in football or not using your stick as a weapon in hockey or lacrosse. While you might see a lot of information on TV or in the news related to the long-term effects of concussions, scientists still have a lot to learn (for more information, see the CDC website [4]). There may be long-term effects of both single and multiple concussions, but we do not know for sure. We also know that playing sports is beneficial for you in other ways, so it is important to 
continue playing but to be as safe as you can, and remember to tell someone if you hit your head so appropriate care can be taken. A healthy healed brain gives you the best chance of doing all you love, and as mom always says, "no more monkeys jumping on the bed."

\section{REFERENCES}

1. Carney, N., Ghajar, J., Jagoda, A., Bedrick, S., Davis-O'Reilly, C., du Coudray, H., et al. 2014. Concussion guidelines step 1: systematic review of prevalent indicators. Neurosurgery 75(S1):S3-15. doi:10.1227/NEU.0000000000000433

2. Giza, C. C., and Hovda, D. A. 2014. The new neurometabilic cascade of concussion. Neurosurgery 75(S4):S24-33. doi:10.1227/NEU.0000000000000505

3. McCrory, P., Meeuwisse, W. H., Aubry, M., Cantu, R. C., Dvorák, J., Echemendia, R. J., et al. 2013. Consensus statement on concussion in sport: the 4th International Conference on Concussion in Sport, Zurich, November 2012. J. Athl. Train. 48(4):554-75. doi:10.4085/1062-6050-48.4.05

4. Center for Disease Control. 2016. Heads Up. Available at: http://cdc.gov/headsup

5. Hall, E. E., Ketcham, C. J., Crenshaw, C., Baker, M., McConnell, J., and Patel, K. 2015. Concussion management in collegiate student-athletes: return-to-academics recommendations. Clin. J. Sport. Med. 25(3):291-6. doi:10.1097/ JSM.0000000000000133

SUBMITTED: 21 March 2016; ACCEPTED: 24 August 2016; PUBLISHED ONLINE: 13 September 2016.

EDITED BY: Fulvio D’Acquisto, Queen Mary University of London, UK

CITATION: Ketcham CJ and Hall EE (2016) Caring for Your Brain: What You need to know about Concussions. Front. Young Minds 4:17. doi:10.3389/frym.2016.00017

CONFLICT OF INTEREST STATEMENT: The authors declare that the research was conducted in the absence of any commercial or financial relationships that could be construed as a potential conflict of interest.

COPYRIGHT @ 2016 Ketcham and Hall. This is an open-access article distributed under the terms of the Creative Commons Attribution License (CC BY). The use, distribution and reproduction in other forums is permitted, provided the original author(s) or licensor are credited and that the original publication in this journal is cited, in accordance with accepted academic practice. No use, distribution or reproduction is permitted which does not comply with these terms. 


\section{REVIEWED BY}

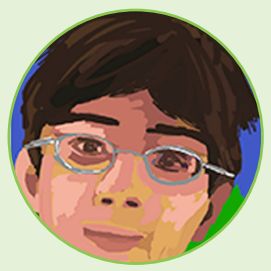

\section{DARIUS, 12 YEARS OLD}

I am 12 years old. In my free time, I enjoy reading and computer programming. As a hobby, I make useful objects and experiment with devices. I am very interested in the environment and was one of the founders of my school's green committee. I enjoy reading about science, particularly chemistry, biology, and neuroscience.

\section{AUTHORS}

\section{CAROLINE J. KETCHAM}

Associate Professor and Chair of Exercise Science, Elon University. My research is in the area of motor control and focuses on how movements are controlled and organized in the brain. I have worked in the area of concussions for 6 years as co-director of Elon BrainCARE with Eric Hall and also do research related to sensorimotor processing in kids.

*cketcham@elon.edu

\section{ERIC E. HALL}

Professor of Exercise Science and Coordinator of Neuroscience Program, Elon University. My research is in the area of exercise psychology and focuses on how movement and physical activity affects mental health. I have worked in the area of concussions for 8 years and co-direct a group with Caroline Ketcham called Elon BrainCARE, which works with our sports medicine staff on concussion management and also researches the influence concussions have on student athletes. 